\title{
Southern Ocean dynamics and biogeochemistry in a changing climate: introduction and overview
}

\author{
Stephanie M. Downes ${ }^{\mathrm{a}}$, Wilbert Weijer ${ }^{\mathrm{b}}$, Nicole Jeffery ${ }^{\mathrm{b}}$, Matthew Mazloff ${ }^{\mathrm{c}}$, Joellen \\ Russell $^{\mathrm{d}}$ \\ ${ }^{a}$ Research School of Earth Sciences and ARC Centre of Excellence for Climate System \\ Science, Australian National University, Acton, Australia \\ Email address: stephanie.downes@anu.edu.au \\ ${ }^{\mathrm{b}}$ Computer and Computational Sciences Division, Los Alamos National Laboratory, Los \\ Alamos, NM \\ c Scripps Institution of Oceanography, La Jolla, CA \\ ${ }^{\mathrm{d}}$ Department of Geosciences, University of Arizona, Tucson, AZ
}

\section{Introduction}

The Southern Ocean has a unique place in our climate system. It is a region of extremes, where the world's strongest ocean currents, the strongest wind regime, the most extensive sea ice cover, and the largest ice sheets interact (for example, see the recent review by Rintoul and Naveira Garabato, 2013). In addition, it houses a very productive ecosystem that sequesters a significant fraction of the anthropogenic CO2 in the ocean (Sabine et al., 2004; Takahashi et al., 2012).

Studying the Southern Ocean has proven to be a significant challenge, for several reasons. Among those are the logistical difficulties of making observations in these remote and vast parts of the world, due also to the harsh weather conditions and extensive sea ice cover in winter months. But arguably a more important factor is the immense complexity of the Southern Ocean climate system, where so many tightly coupled components interact on so many temporal and spatial scales. A case in point is the surprising expansion of winter sea ice in the Weddell Sea in recent years, amidst significant warming trends (Barthélemy et al., 2012; Mathiot et al., 2010; Stössel et al., 2011).

Yet, our understanding of the Southern Ocean climate system is rapidly improving and evolving. The expansion of autonomous observation platforms and remote sensing techniques is quickly enhancing the spatial and temporal coverage of some key climate observables; and several decades of high-quality hydrographic observations have allowed us to assess changes in the Southern Ocean on climatologically relevant time scales (e.g., Gille, 2002; Purkey and Johnson, 2010; Kouketsu et al., 2011). Furthermore, significant progress in numerical modeling approaches have increased the complexity and realism of global coupled climate models (see, for example, an extensive review of climate models in Randall et al., 2007; Flato et al., 2007); and models that explicitly resolve the mesoscale are starting to become feasible research tools (e.g., Morrison and Hogg, 2013; Meredith et al., 2012).

The papers in this special volume of Deep-Sea Research II provide a case in point. They cover a wide range of topics related to the Southern Ocean climate system, and explore 
and showcase a variety of methods that further our understanding of its dynamics and biogeochemistry. This special issue was motivated by the session "the Southern Ocean and its role in the climate system”, at the 2012 AGU/ASLO Ocean Sciences Meeting in Salt Lake City, Utah.

\section{Overview of contributions to the volume}

Weijer (2015) uses a barotropic shallow-water model to study the wind- driven variability in the Southeast Pacific Ocean. In particular, he examines the energetics of modes of variability that are trapped by the Amundsen, Bellingshausen, and Mornington Abyssal Plains. The analysis shows that roughly a quarter of the wind power that forces the barotropic circulation in the region is used to excite a spatially coherent mode that encompasses almost the entire Southeast Pacific Basin. For specific events of strong and persistent wind forcing (like the well-known event in late 2009), this contribution rises to almost 50\%. This energy is expended at a few specific locations, most importantly the Eltanin Fracture Zone and the crest of the East Pacific Rise. These regions may be prominent locations for deep ocean mixing and strong frictional dissipation.

Moving eastward, Vivier et al. (2015) study the variability of a branch of the Antarctic Circumpolar Current that passes through the Fawn Trough, the only deep passage across the Kerguelen Plateau. Using a year's worth of current meter data they find a transport of $34 \pm 6$ Sv. They further show that Fawn Trough transport variability can be confidently estimated from altimeter data, showing that it is possible to observe this branch of the ACC remotely. Using a transport time series that was extended to 20 years by the altimeter observations, the authors show that on interannual time scales the Fawn Trough transport is enhanced by increased winds associated with a positive phase of the Southern Annular Mode (SAM), as well as by anomalous ENSO events (e.g., 1997-1998).

Farther downstream, Katsumata et al. (2015) study changes in the properties of Antarctic Bottom Water along $62^{\circ} \mathrm{S}$ in the Australian-Antarctic Basin. In particular, they observe a significant freshening and warming between 1995/1996 and 2012/2013, as well as an increase in the concentration of dissolved oxygen. The authors argue that the changes can partly be explained by a poleward shift of the water mass structure of the Southern Ocean. However, the freshening and increases in oxygen concentration point to changes in the provenance of AABW in the region as well.

Martin et al. (2015) explore the global impact of changes in Antarctic Bottom Water formation, as they argue for a critical role of Weddell Sea deep convection in multicentennial variability in their coupled climate model. They show how the build-up of a subsurface reservoir of heat in the Weddell Sea is followed by episodes of strong convection and AABW formation. The periods of enhanced AABW export coincide with reduced NADW export from the Atlantic, revealing a bipolar seesaw relationship and hence a global impact of convection variability in the Weddell Sea. The authors note that the redistribution of heat has a clear signature in sea level in the Southern Ocean and subpolar North Atlantic, and that these sea level changes rival observed 20th century sea 
level rise in magnitude.

The final two papers highlight the biogeochemical relevance of the Southern Ocean. Munro et al. (2015) study net community production in the Drake Passage, using a decade's worth of cruise data. In particular, they use insitu observations of nutrients, dissolved inorganic carbon, and surface ocean pCO2 to diagnose seasonal net community production rates, and to validate a suite of satellite-based algorithms. The authors find that the satellite-based estimates differ considerably, but bracket the budget-based estimates. But more importantly, the satellite-based methods fail to capture the dominance of the spring bloom that is apparent from in-situ observations. Surprisingly, the budget-based time series correlate negatively with the SAM index on interannual time scales.

Melbourne-Thomas et al. (2015) address the problem of calibrating a simple model of the biogeochemical cycles in the Southern Ocean. Their optimal control approach allows certain parameters to vary in time, in contrast to more conventional procedures where an optimal combination of fixed parameter values is sought. They apply this approach to study the productivity at two locations in the Australian-Antarctic Basin, namely the Subantarctic Front (SAF) and the Polar Front (PF). Their results suggest that photosynthetic efficiency is higher during winter than during summer, allowing phytoplankton to more efficiently use the limited light during winter months. In addition, the results highlight the importance of zooplankton grazing on phytoplankton biomass in the iron-limited SAF and PF regions.

\section{Conclusions}

Results from the above contributions combine climate models and observations to demonstrate ways in which we can isolate and study individual climate events amidst long term atmospheric observations (Weijer, 2015), link these observations with interannual variations in the regional Antarctic Circumpolar Current transport (Vivier et al., 2015), detect decadal changes in Antarctic Bottom Water properties (Katsumata et al., 2015) and explore the influence of its export on the North Atlantic on centennial timescales (Martin et al., 2015), and utilize satellite data, in situ observations, and alternate modelling methods to evaluate seasonal biological processes (Munro et al., 2015; Melbourne-Thomas et al., 2015).

The articles herein are a small but significant step in extricating major Southern Ocean scientific issues, and identifying the role of the Southern Ocean climate in influencing the remainder of the global ocean in the past, present, and future states. What remains is an outstanding demand for improved sampling of the deep Southern Ocean on a regional scale, high resolution model sensitivity experiments, continuous measurements of key water mass properties and key areas of interest (such as those with topographical constraints), and international collaborations that will facilitate these resource-intensive projects. 


\section{Acknowledgements}

S. M. Downes was supported by the ARC Centre of Excellence for Climate System Science (grant CE110001028). W. Weijer was supported by the Regional and Global Climate Modeling program of the US Department of Energy Office of Science. Los Alamos National Laboratory is operated by the Los Alamos National Security, LLC for the National Nuclear Security Administration of the U.S. Department of Energy under contract DE-AC5206NA25396.

\section{References}

Barthélemy, A., Goosse, H., Mathiot, P., Fichefet, T., 2012. Inclusion of a katabatic wind correction in a coarse-resolution global coupled climate model. Ocean Model. 48, 45-54.

Flato, G., Marotzke, J., Abiodun, B., Braconnot, P., Chou, S., Collins, W., Cox, P., Driouech, F., Emori, S., Eyring, V., Forest, C., Gleckler, P., Guilyardi, E., Jakob, C., Kattsov, V., Reason, C., Rummukainen, M., 2007. Cilmate models and their evaluation, in: Stocker, T.F., Qin, D., Plattner, G.K., Tignor, M., Allen, S.K., Boschung, J., Nauels, A., Xia, Y., Bex, V., Midgley, P.M. (Eds.), Climate Change 2013: The Physical Science Basis. Contribution of Working Group I to the Fifth Assessment Report of the Intergovernmental Panel on Climate Change. Cambridge University Press, Cambridge, United Kingdom and New York, NY, USA, pp. 741-866.

Gille, S.T., 2002. Warming of the Southern Ocean. Science 295, 1275-1277.

Katsumata, K., Nakano, H., Kumamoto, Y., 2015. Dissolved oxygen change and freshening of Antarctic Bottom Water along in the Australian - Antarctic Basin between 1995/96 and 2012/13. Deep-Sea Res. II This issue.

Kouketsu, S., Doi, T., Kawano, T., Masuda, S., Sugiura, N., Sasaki, Y., Toyoda, T., Igarashi, H., Kawai, Y., Katsumata, K., Uchida, H., Fukasawa, M., Awaji, T., 2011. Deep ocean heat content changes estimated from observation and reanalysis product and their influence on sea level change. J. Geophys. Res. 116.

Martin, T., Park, W., Latif, M., 2015. Southern Ocean forcing of the North Atlantic at multi-centennial time scales in the Kiel Climate Model. Deep- Sea Res. II This issue.

Mathiot, P., Barnier, B., Gall' ee, H., Molines, J.M., Sommer, J.L., Juza, M., Penduff, T., 2010. Introducing katabatic winds in global ERA40 fields to simulate their impacts on the Southern Ocean and sea-ice. Ocean Model. 35, 146-160.

Melbourne-Thomas, J., Wotherspoon, S., Corney, S., Molina-Balari, E., Marini, O., Constable, A., 2015. Optimal control and system limitation in a Southern Ocean ecosystem model. Deep-Sea Res. II This issue.

Meredith, M.P., Naveira-Garabato, A.C., Hogg, A.M., Farneti, R., 2012. Sensitivity of 
the overturning circulation in the Southern Ocean to decadal changes in wind forcing. J. Climate 25, 99-110.

Morrison, A.K., Hogg, A.M., 2013. On the relationship between Southern Ocean overturning and ACC transport. J. Phys. Oceanogr. 43, 140-148.

Munro, D.R., Lovenduski, N.S., Stephens, B.B., Newberger, T., Arrigo, K.R., Takahashi, T., Quay, P.D., Sprintall, J., Freeman, N., Sweeney, C., 2015. Estimates of net community production in the Southern Ocean determined from time series observations (2002-2011) of nutrients, dissolved inorganic carbon, and surface ocean pCO2 in Drake Passage. Deep-Sea Res. II This issue.

Purkey, S.G., Johnson, G.C., 2010. Warming of global abyssal and deep Southern Ocean waters between the 1990s and 2000s: Contributions to global heat and sea level rise budgets. J. Clim. 23, 6336-6351.

Randall, D.A., Wood, R.A., Bony, S., Colman, R., Fichefet, T., Fyfe, J., Kattsov, V., Pitman, A., Shukla, J., Srinivasan, J., Stouffer, R.J., Sumi, A., Taylor, K.E., 2007. Cilmate models and their evaluation, in: Solomon, S., D. Qin, M.M., Chen, Z., Marquis, M., Averyt, K., M.Tignor, Miller, H. (Eds.), Climate Change 2007: The Physical Science Basis. Contribution of Working Group I to the Fourth Assessment Report of the Intergovernmental Panel on Climate Change. Cambridge University Press, Cambridge, United Kingdom and New York, NY, USA.

Rintoul, S.R., Naveira Garabato, A.C., 2013. Chapter 18 - Dynamics of the Southern Ocean circulation, in: Gerold Siedler, Stephen M. Griffies, J.G., Church, J.A. (Eds.), Ocean Circulation and Climate A 21st Century Perspective. Academic Press. volume 103 of International Geophysics, pp. $471-492$.

Sabine, C.L., Feely, R.A., Gruber, N., Key, R.M., Lee, K., Bullister, J.L., Wanninkhof, R., Wong, C.S., Wallace, D.W.R., Tilbrook, B., Millero, F.J., Peng, T.H., Kozyr, A., Ono, T., Rios, A.F., 2004. The oceanic sink for anthropogenic CO2. Science 305, 367-371.

Stössel, A., Zhang, Z., Vihma, T., 2011. The effect of alternative real-time wind forcing on Southern Ocean sea-ice simulations. J. Geophys. Res. 116, 1-54.

Takahashi, T., Sweeney, C., Hales, B., Chipman, D.W., Newberger, T., Goddard, J.G., Iannuzzi, R.A., Sutherland, S.C., 2012. The changing carbon cycle in the Southern Ocean and sea-ice. Oceanogr. 25, 26-37.

Vivier, F., Park, Y.H., Sekma, H., Le Sommer, J., 2015. Variability of the Antarctic Circumpolar Current transport through the Fawn Trough, Kerguelen Plateau. Deep-Sea Res. II This issue.

Weijer, W., 2015. Modal variability in the Southeast Pacific Basin: Energetics of the 2009 event. Deep-Sea Res. II This issue. 